\title{
Moving Toward Sustainable Design through the Utilization of Economic Input-Output-Based Life Cycle Assessment Methods
}

\author{
Thomas M. Ferguson, Jonathan Norman, and Heather L. MacLean \\ Department of Civil Engineering, University of Toronto \\ Corresponding Author: hmaclean@ecf.utoronto.ca
}

\begin{abstract}
An Economic Input-Output based Life Cycle-based Assessment tool developed for the Canadian economy is presented, which estimates selected environmental implications (e.g. energy use, greenhouse gas emissions) throughout the entire economy associated with given demand for a product/material. An example application illustrates a comparison between concrete and steel use for columns in office buildings. Steel columns are found to be more energy intensive, but both column types result in similar levels of greenhouse gas emissions. The model's advantages and limitations as a tool to assist designers in evaluating the environmental implications of their designs are discussed.
\end{abstract}

\section{Introduction}

The provision of all products and services results in impacts on our environment. In recent years firms and their designers have been under increasing economic, regulatory, and consumer pressure to make their products and services more sustainable. The entire life cycle of a product from "cradle to grave" (including design and development, raw material extraction, material production, manufacture, use and end-of-life) determines its environmental performance. Only by considering the entire life cycle is it possible for designers to determine whether an alternative design has the potential for lower environmental impact. Thus firms must have methods and tools appropriate for informing decisions about various design options prior to committing substantial resources for $\mathrm{R} \& \mathrm{D}$ on options that a life cycle-based analysis would demonstrate were not environmentally desirable.

In recent years, the understanding of these impacts has improved with the development of novel life cycle assessment (LCA) techniques that incorporate economic input-output accounts to estimate the environmental burdens across an industry's entire supply chain. LCA is a systematic tool to inform design and manufacturing decisions about the environmental impacts of materials, products and processes. Economic Input-Output LCA (EIO-LCA) in particular allows for quick and accurate estimation of the economy-wide environmental effects of different production decisions. In a conventional LCA, the scope of a study is limited by the complexity and timeconsuming nature of data collection and by the amount of detail required for a thorough analysis. Therefore results can vary widely between studies. EIO-LCA overcomes these problems by using a consistent boundary (the entire economy) with publicly available data.

In this paper, we present an EIO-LCA model we have developed for Canada that estimates the energy use and greenhouse gas (GHG) emissions associated with a given demand for particular products and services. The model helps provide a standardized methodology for LCA research in Canada as it is based on high quality economic and environmental data from Statistics Canada. It has been developed with the ultimate intention of creating a North American, multiregional model. Such a model could not only help standardize and facilitate LCA in North America, but could also feature in the analysis of environmental policies. Therefore our broad objective is to facilitate sustainable design and policymaking in North America through the development and application of environmental decision-making tools.

The specific objective in this paper is to illustrate the potential of the Canadian EIO-LCA model for determining the environmental implications of material selection in design. In our example application, the energy use and GHG emissions resulting from concrete vs. steel columns in a typical office building are calculated. The discussion ends with a ranking of sectors by energy use intensity. 


\section{Background and Theory}

LCA is a technique whereby the environmental impacts of the steps of in a product or process' life cycle are determined and evaluated [1]. The International Organization for Standardization (ISO) has published frameworks for LCA as part of their environmental management system [2]. The conventional framework for LCA in North America is based on that developed by the Society of Environmental Toxicology and Chemistry (SETAC) [3] and the U.S. Environmental Protection Agency (USEPA). The life cycle stages and material and energy flows inventoried in a cradle-to-grave LCA are shown in

Figure 1.

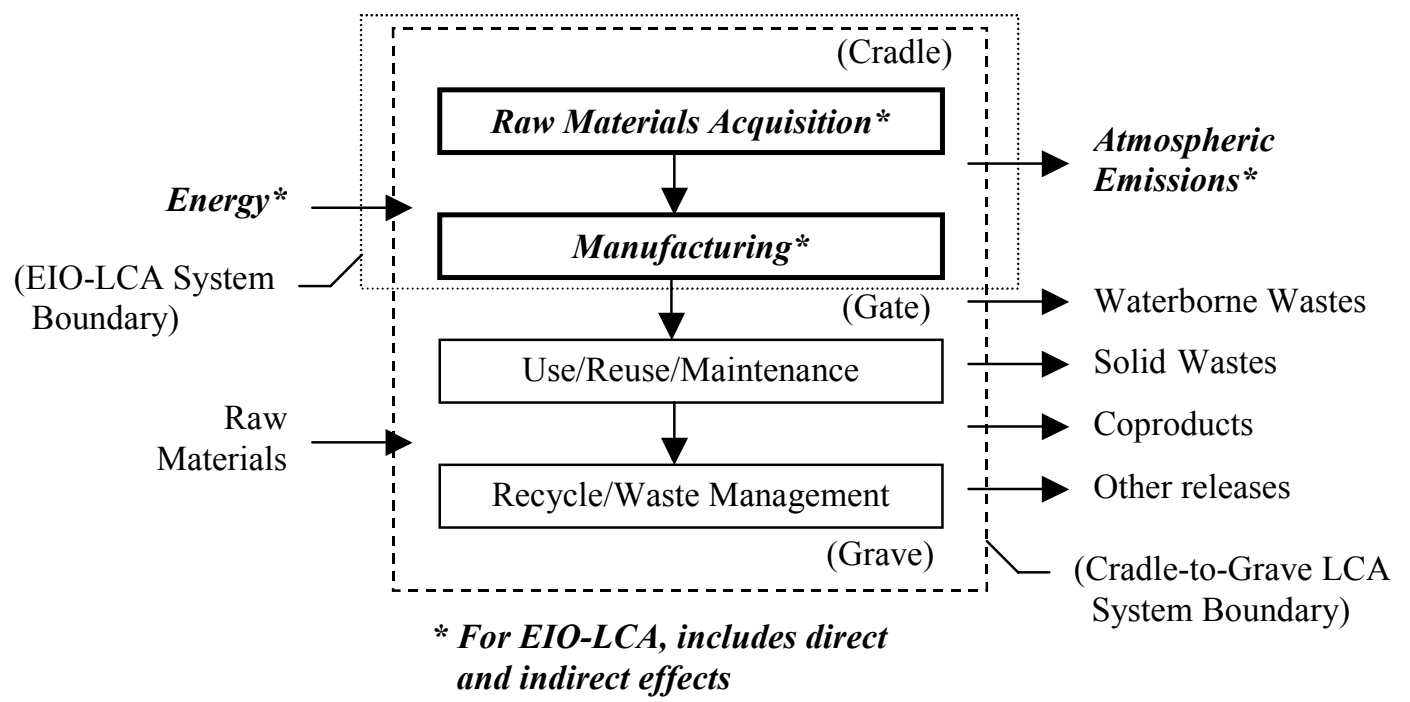

Figure 1: Conceptual Diagram of Life-Cycle Stages and their Inventoried Flows. (Adapted from USEPA [1])

A second framework for LCA is based on Economic Input-Output Analysis. Input-output analysis was developed by Wassily Leontief in 1941 [4]. The extension of a single-region Economic Input-Output model to Life Cycle Assessment was introduced by researchers at Carnegie Mellon University (CMU) [5] and has since been applied to a variety of examples in the U.S. [6-10]. An on-line version of the U.S. EIOLCA model developed at CMU and based on the Bureau of Economic Analysis (BEA) benchmark industry-by-industry input-output tables for 1997 is available [11]. The comparable Canadian EIO-LCA model was developed by Bjorn [12] and refined by Norman for application to the bi-national, Canada-U.S. multiregional case [13]. The model has been applied to a preliminary survey of the top greenhouse gas (GHG) emitting sectors, and to the evaluation of a reinforced concrete highway [12].

There are several essential features that distinguish EIO-LCA from conventional, SETAC/EPA LCA, the first two of which are alluded to in Figure 1. First, whereas conventional LCA, the entire life cycle from cradle to grave can be analyzed, EIO-LCA is most naturally suited to cradle-to-gate analyses because the data collected for the model are from producers of products and services in the economy. Second, whereas in conventional LCA, the boundary can be selected by the analyst to include any range of supply chain processes, in EIO-LCA the boundary is automatically set to be the whole economy. Therefore in conventional LCA the study of supply chain impacts is limited to the extent of the boundary selected, while EIO-LCA automatically includes the entire production supply chain of a product or process in the analysis, including indirect effects (discussed in detail in Hendrickson et. al. [5]). For instance, an EIO-LCA study of car manufacture would consider not only releases to the environment by the manufacturer itself as well as its direct suppliers, but also contributions by indirect suppliers across the entire supply chain (e.g. electricity for steel production, coal mining for electricity generation, drilling services for coal mining, etc) [12]. Due to the excessive time required to gather indirect effect data, they are not considered in conventional LCA. Therefore compared to EIO-LCA, conventional LCA will typically underestimate the 
supply chain impacts of the production process. Third, whereas in conventional LCA inputs and outputs can be measured empirically or modelled accurately with any relevant mathematical formulation, EIO-LCA assumes that releases to the environment are linearly proportional to levels of economic activity. Fourth, EIO-LCA uses monetary transactions between sectors as a surrogate for physical commodity flows. This is distinct from conventional LCA: consider the LCA of a steel kitchen knife with a plastic handle for example. In a conventional LCA the supply-chain processes for the manufacture of both the polymer and the steel, followed by the assembly process would be examined in detail. For an EIO-LCA, the monetary value of the handle and the blade would be estimated and assigned to the most closely matching industrial sector. These estimates would be entered into the EIO-LCA model, which would compute the economy-wide, supply-chain inputs and outputs automatically.

\section{Mathematical Basis}

At the heart of the EIO-LCA model are national input-output tables, whose detailed development is outlined in Miller and Blair [14]. The economy is divided into industrial sectors, where companies making similar products with similar techniques are grouped (the list of industrial sectors used as a basis for the Canadian model in this paper are listed in Appendix A). Input-output models are linear, and provide first-order economic impacts. An input-output table is a two-dimensional matrix, $\mathbf{Z}$, whose $z_{i j}$ elements represent the total purchases from industry ' $i$ ' by industry ' $j$ ' for one year. In order to use the inputoutput tables for EIO analysis, each of the $\mathrm{z}_{\mathrm{ij}}$ elements is divided by the total output for industry ' $\mathrm{i}$ '. The result is a square matrix $\mathbf{A}$, called the technical coefficient matrix, whose $a_{i j}$ elements represent the dollar amount of purchases from industry ' $i$ ' by industry ' $j$ ' per dollar output from industry ' $i$ '.

Letting $\mathbf{X}$ be the vector of total outputs from each sector of the economy and $\mathbf{Y}$ be the vector of final consumer demands for each industry's products and services, equation (1) states that the output from each sector will equal the sum of demands from other industries plus final demand from consumers.

$$
\mathbf{X}=\mathbf{A X}+\mathbf{Y}
$$

Solving for the vector $\mathbf{X}$, results in the following equation:

$$
\mathbf{X}=(\mathbf{I}-\mathbf{A})^{-1} \mathbf{Y}
$$

The matrix $(\mathbf{I}-\mathbf{A})^{-1}$ is called the Leontief inverse, or alternately the total requirements matrix (TRM). It enables the computation of purchases throughout the entire economy required to meet a specified final demand, including direct and indirect effects. The
TRMs can be obtained from national statistical agencies in Canada and the U.S., which publish them for use in input-output models.

EIO-LCA rests on the extension of the monetary input-model discussed above to estimate environmental inputs, and outputs, according to equation (3):

$$
\mathbf{E}=\hat{\mathbf{C}} \mathbf{X}
$$

The $\mathrm{e}_{\mathrm{i}}$ element of a vector $\mathbf{E}$ is the environmental input or output for the sector 'i'. For each environmental vector $\mathbf{E}$ there is a corresponding set of environmental coefficients $\hat{\mathbf{C}}$. Each matrix $\hat{\mathbf{C}}$ is a diagonal matrix whose $c_{i i}$ elements are environmental input or output coefficients. The diagonal elements are obtained by dividing the total environmental input or output for each industry by its total economic output. For example, the GHG emissions coefficient $p_{i i}$ for the industry ' $i$ ' in Canada are determined by dividing the total amount of GHG (in g) emitted by industry ' $i$ ' by its total output (in $\$ \mathrm{CDN}$ ).

\section{Method}

\section{Data Sources}

Our model was implemented in MATLAB using 1997 data from Statistics Canada. The base year 1997 was selected because it matched the base year of the most recent comprehensive benchmark EIO data published by the Bureau of Economic Analysis in the U.S., which was beneficial in light of our intent to implement a Canada-U.S. bi-national model [13]. Due to the sizes and "mature" structures of the U.S. and Canadian economies, the technical coefficients generally do not vary substantially from year to year. Hence the estimation of current impacts with the 1997 data is considered reasonable and is commonly applied. The total requirements matrix used was that provided by Statistics Canada's Canadian System of National Accounts (CSNA). Statistics Canada compiles four different IO tables, the S, or small level matrices, the $\mathrm{M}$, or medium level matrices, the $\mathrm{L}$, or large level matrices, and the $\mathrm{W}$, or worksheet level matrices. S, M, L and $\mathrm{W}$ refer to the level of sectoral detail, with the worksheet level being the most disaggregated. We employed the L-level table, which best combines disaggregation and quality and includes 117 sectors (listed in Appendix A). The sectors are based on the North American Industry Classification System (NAICS), which enables standardization of data between the U.S., Mexico and Canada [15].

The environmental release data was obtained from Statistics Canada's Econnections package [16], in which indicators are published that establish connections between economic and environmental performance in Canadian industries. As part of the 
Canadian System of Environmental and Resource Accounts (CSERA) that is used in tandem with the CSNA to create economic-environmental indicators, environmental performance data is collected from producers to create national Material and Energy Flow Accounts (MEFA).

The environmental metrics considered in our model, GHG gas emissions and energy use, detailed in Table 1. The measure of greenhouse gas emissions combines estimates of carbon dioxide, methane and nitrous oxide from various sources into a single measure with units of equivalent grams of $\mathrm{CO}_{2}\left(\mathrm{~g} \mathrm{CO}_{2}\right.$ eq.) [17]. The gases are weighted according to their global warming potential (GWP), with $\mathrm{CO}_{2}$ given a GWP weight of 1 . Because methane and nitrous oxide are more effective at capturing the reflections of the sun's rays off of the earth's surface, they are assigned higher GWPs of 21 and 310 respectively. Though halocarbons have higher GWPs than these substances, it is considered that there is insufficient data to confidently estimate their contribution to global warming potential by industry and they are not included in the GHG measure [17]. Because most of the carbon in fuel burning reactions that are used to estimate the $\mathrm{CO}_{2}$ releases in the economy is burned, $\mathrm{CO}_{2}$ estimates are considered to be of high quality, whereas methane and nitrous oxide production are considered to be of fair quality only [17].

Table 1: Summary of Input and Output Coefficients Considered in Canadian EIO-LCA Model

\begin{tabular}{lc}
\hline Description & \multicolumn{1}{c}{ Unit } \\
\hline Greenhouse gas emissions & $\begin{array}{c}\text { g CO } 2 \text { eq./ } 1997 \\
\text { \$CDN }\end{array}$ \\
\hline Total energy input & $\mathrm{TJ} / 1997$ \$CDN \\
\hline Electricity used & $\mathrm{TJ} / 1997$ \$CDN \\
\hline Coal energy input & $\mathrm{TJ} / 1997$ \$CDN \\
\hline Natural gas energy input & $\mathrm{TJ} / 1997$ \$CDN \\
\hline Liquid petroleum gas energy input & $\mathrm{TJ} / 1997$ \$CDN \\
\hline Motor gasoline energy input & $\mathrm{TJ} / 1997$ \$CDN \\
\hline Diesel fuel energy input & $\mathrm{TJ} / 1997$ \$CDN \\
\hline Aviation fuel energy input & $\mathrm{TJ} / 1997$ \$CDN \\
\hline Light fuel oil energy input & $\mathrm{TJ} / 1997$ \$CDN \\
\hline Heavy fuel oil energy input & $\mathrm{TJ} / 1997$ \$CDN \\
\hline Coke energy input & $\mathrm{TJ} / 1997$ \$CDN \\
\hline
\end{tabular}

Energy consumption data from mining industries is collected in the Census of Mines Quarries, and Sandpits, and energy consumption data from the manufacturing industries is collected in the Annual Survey of Manufacturers [17]. Because energy consumption data are not as readily available from the other sectors of the economy such as institutions, their energy usage is estimated by using the Quarterly Report on Energy Supply-Demand in Canada in tandem with the national IO accounts [17].
Coefficients for GHG emissions and energy inputs in our model were derived by dividing the CSERA-listed values for each of the 117 industry sectors by the total monetary value of production from each sector listed in the CSNA for 1997.

It is also possible to consider other environmental metrics in Canadian EIO-LCA, ranging from resource use to toxic emissions reported in the National Pollutant Release Inventory (NPRI). The actual inclusion of these metrics is currently limited by data availability and compatibility with NAICS. However, over time, their inclusion will offer added detail to EIO-LCA modelling in Canada.

\section{Application}

A comparison of economic impacts, GHG emissions and energy use for the manufacture and installation of reinforced concrete vs. steel columns in an office building was undertaken. A 140,000 sq. ft. office building, with 15 storeys and a $10 \mathrm{ft}$ inter-floor span was selected as a basis for calculations. Values used in the analysis were taken from an RSMeans 1999 handbook for building construction estimating in the U.S. [18]. A 700 KIPS steel I-beam column and a 700 KIPS C.I.P., square-tied (concrete) column with minimum reinforcing were selected as representative columns. It was assumed that the metal reinforcement in the concrete column has negligible economic impacts.

Using the RSMeans manual, total material and installation costs were determined. These were converted into $\$ 1999 \mathrm{CDN}$ using the purchasing power parities (PPP) for Canada and the U.S. [19]. \$1999 $\mathrm{CDN}$ values were then converted to $\$ 1997 \mathrm{CDN}$ values using the Canadian Consumer Price Index (CPI) [20]. Material and labour costs were entered as final demands into equation (2) in order to compute direct and indirect economic output resulting from manufacture and installation of both column types. The 'primary metal manufacturing' and 'cement and concrete product manufacturing' sectors were respectively used to approximate the manufacture of steel and concrete columns, and the "non-residential building construction' sector was used to approximate installation for both column types. Direct, indirect, and total GHG emissions and energy use were then computed using equation (3).

\section{Results and Discussion}

The summary comparison of the results for steel and concrete columns in office buildings is shown in Table 2. 
Table 2: Comparison of Economic Impact, Total Energy Use and GHG Emissions for Concrete vs. Steel Columns in a 140,000 sq. ft., 15 Storey Office Building

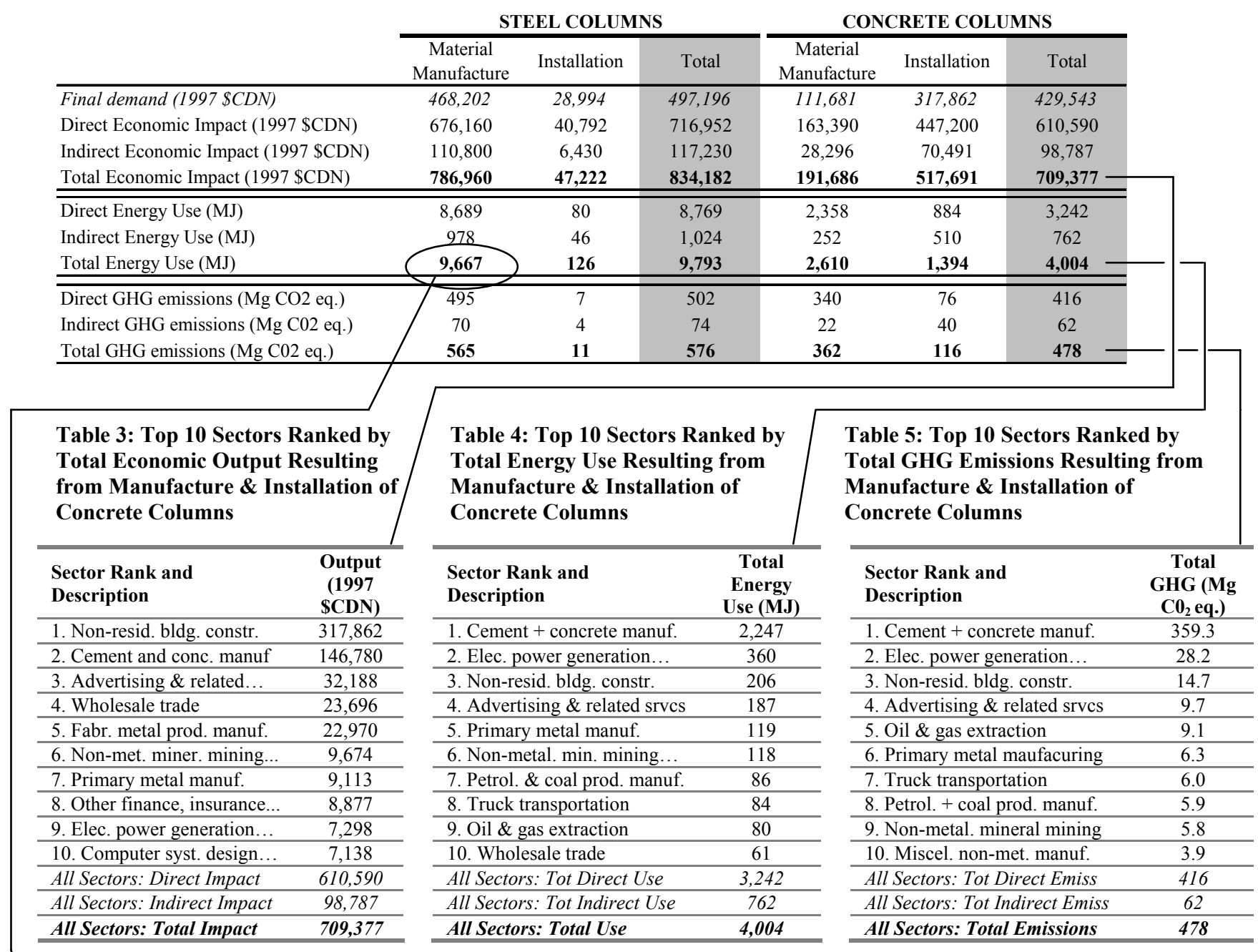

Table 6: Top 10 Sectors Ranked by Energy Use Resulting from Manufacture of Steel Columns

\begin{tabular}{lc}
\hline Sector Rank and Description & $\begin{array}{c}\text { Total } \\
\text { Energy } \\
\text { Use (MJ) }\end{array}$ \\
\hline 1. Primary metal manufacturing & 7,002 \\
\hline 2. Elec. power generation, transm... & 1,266 \\
\hline 3. Metal ore mining & 478 \\
\hline 4. Oil \& gas extraction & 132 \\
\hline 5. Truck transportation & 108 \\
\hline 6. Pipeline transportation & 77 \\
\hline 7. Petroleum \& coal products manuf & 67 \\
\hline 8. Wholesale trade & 64 \\
\hline 9. Basic chemical manufacturing & 61 \\
\hline 10. Rail transportation & 55 \\
\hline All Sectors: Direct Use & 8,689 \\
\hline All Sectors: Indirect Use & 978 \\
\hline All Sectors: Total Use & $\mathbf{9 , 6 6 7}$ \\
\hline
\end{tabular}

Table 7: Distribution of Energy Sources for 'Primary Metal Manufacturing' Sector in the Manufacture of Steel Columns

\begin{tabular}{llcc}
\hline Energy Source & $\begin{array}{c}\text { Total } \\
\text { Energy } \\
\text { Use (MJ) }\end{array}$ & $\begin{array}{c}\text { Energy Use } \\
\text { Proportion } \\
\text { (\%) }\end{array}$ \\
\hline Electricity & 2,404 & 34.3 \\
\hline Coal & 183 & 2.6 \\
\hline Natural gas & 2,166 & 40.9 \\
\hline Liquid petroleum gas & 481 & 6.9 \\
\hline Motor gasoline & 6 & 0.1 \\
\hline Diesel fuel & 19 & 0.3 \\
\hline Aviation fuel & 0 & 0.0 \\
\hline Light fuel oil & 16 & 0.2 \\
\hline Heavy fuel oil & 231 & 3.3 \\
\hline Coke & 1497 & 21.4 \\
\hline
\end{tabular}


The total costs of manufacture and installation are listed as 'Final demands' in Table 2. Steel columns are expensive to manufacture $(\$ 468,202)$, but relatively inexpensive to install $(\$ 28,994)$. The opposite is true of the concrete columns, which are less expensive to manufacture $(\$ 111,681)$ than to install $(\$ 317,862)$. However, their overall costs are close. The main result is that for comparable costs, while the GHG emissions for the steel column case (576 $\mathrm{Mg} \mathrm{CO}_{2}$ eq.) are $20 \%$ larger than the $\mathrm{GHG}$ emissions for the concrete column case (478 $\mathrm{Mg} \mathrm{CO}_{2}$ eq.), the energy uses for the steel case $(9,793 \mathrm{MJ})$ are $144 \%$ larger than for the concrete case (4,004 MJ). This suggests that from an energy standpoint, the use of steel columns in buildings is less sustainable than the use of concrete columns. For the implicit timeline used in our study, we have assumed that the building will not be demolished, which is a reasonable assumption considering the superstructure of an office building generally stays constant through renovations during the building's life.

For the steel columns, the energy use and GHG emissions are largest where there is the largest economic activity. Hence, the larger economic output associated with steel column manufacture results in greater energy use for manufacture compared to installation. However for concrete columns the trend is reversed: there is more economic activity associated with installation, but there are greater energy use and GHG emissions associated with manufacture. The primary reason for the reversal is that concrete manufacture is more energy and GHG emission intensive than non-residential construction. In other words, there is less energy use and there are fewer $\mathrm{CO}_{2}$ emissions per dollar of economic activity in construction than per dollar of economic activity in concrete manufacture.

Also shown in Table 2 are the direct and indirect economic impacts resulting from the purchase and installation of the columns, and their associated energy use and GHG emissions. In all cases, the total economic impact is larger than the final demand due to supply chain effects. These are shown more clearly in Table 3, which ranks the top 10 sectors based on economic activity resulting from the manufacture and installation of the concrete columns. In order for the 'cement and concrete product manufacturing' industry to produce $\$ 111,681$ of saleable concrete, it must purchase products and services from other economic sectors, such as non-metallic ores to feed chemical reactions, electricity to power process plants, and insurance to protect investments. These industries in turn purchase concrete and cement to build their infrastructure, which increases the production of concrete and cement over the $\$ 111,681$ mark. Moreover, firms within the cement and concrete manufacturing industry purchase the sector's products for their operations. Based on this logic, the total economic output in the 'non-residential building construction' sector should also exceed the final demand of $\$ 317,862$. However, there are five sectors of the 117 in the model where Statistics Canada has not provided detailed inter-sectoral information in its total requirements matrix, and the 'non-residential building construction sector' is included in this number. Therefore we assumed that economic activity in this sector resulted only from final demand, and that there were no interrelated impacts (this was achieved by placing a ' 1 ' on the $13^{\text {th }}$ row and $13^{\text {th }}$ column entry of the TRM, and ' 0 's in the rest of the $13^{\text {th }}$ row).

A sense of this assumption's impact on our results was obtained by using the 1997, CMU U.S. EIO-LCA model [11]. It was found that for a final demand of $\$ 317,862$, the total economic output is $\$ 637,604$, which causes the GHG emissions and energy use to roughly double compared to the Canadian case. Assuming that the U.S. economy is structurally similar to the Canadian economy (which we have yet to validate), the implication is that we may be underestimating our GHG emissions and energy uses by a factor of 2. However, this does not drastically change the sustainability comparison between column types. Doubling the GHG emissions and energy use resulting from activities associated with final demand in the 'non-residential construction' sector causes the GHG emissions for both column types to become nearly equal, and decreases the ratio of energy use for the steel to concrete column case from 2.4 to 1.8 . Therefore, the GHG emissions are still essentially comparable, whereas the total energy use associated with steel columns in office towers remains much larger than the energy use associated with concrete columns.

In Table 4, the top 10 energy-using sectors resulting from the manufacture and installation of concrete columns are ranked. The total energy used is 4,004 MJ. Overall, there is a correspondence between energy use and economic output such that the top 10 sectors for both metrics are similar. However, the sector order is different in Table 4 than in Table 3 because sectors involved in electricity generation, either directly or through extraction of raw energy products, are more energy intensive and are therefore more highly ranked in the energy use category than in the economic impact category. The 'electricity generation, transmission and distribution' sector does not represent the energy produced by the sector, but the energy used by the sector to generate the electricity that is purchased by other sectors.

Though the quality of energy use estimates is considered to be good due to the fact that industrial 
producers are required to report quantities of energy purchased and sold yearly [17], the EIO-LCA analyst should cross-check energy use with other sources if performing an LCA for a particular geographic region. As with many of the values computed by the EIO-LCA model, the values are based on national, aggregate measures. The energy mix varies from province to province, and from municipality to municipality across the country. In certain localities, there might be a greater proportion of hydro electricity generation (for example) in the electricity mix than that considered by the EIO-LCA model, which is based on the average Canadian electricity generation mix.

In Table 5 the top 10 GHG-emitting sectors associated with the manufacture and installation of concrete columns are ranked. The total emissions are $478 \mathrm{Mg} \mathrm{CO} 2$ eq. In this case the rankings are very similar to the rankings for energy use because there is a high correlation between energy use and GHG emissions. Ninety percent of the $\mathrm{CO}_{2}$ emissions reported by Statistics Canada are from the combustion of fossil fuels [17]. Of the other $10 \%$, a significant component is the emissions from chemical reactions involved in the production of cement and lime [17]. Therefore the 'cement and concrete product manufacturing' sector is inherently emissionsintensive, which is why there is a larger gap between the first and second ranked sectors in the GHG emissions table than in the energy use table. The fuels burned in the extraction of inputs to the production of cement and concrete appear as GHG emissions in the 'non-metallic, mineral mining and quarrying sector'; GHG emissions from the generation of electricity are represented in the 'electric power generation, transmission and distribution' sector emissions; and GHG emissions from the extraction of fuels burned in electricity generation are represented in the 'oil and gas extraction' and in the 'petroleum and coal products manufacturing' sector emissions. Finally, GHG emissions from the fuels burned in the shipment of materials related to the cement and concrete industry are represented in the transportation sectors emissions.

Turning now to the steel column case, Table 2 shows that the total energy use for column manufacture represents $99 \%$ of the total energy use. Therefore, in Table 6 the top 10 energy-using sectors resulting from only the manufacture of steel columns are ranked. The total energy used in manufacture is 9,667 $\mathrm{MJ}$, and similar sectors as for the concrete column case appear in the ranking, with the notable exception of the 'cement and concrete product manufacturing' sector. Most of the energy use is concentrated in the 'primary metal manufacturing sector', which was used to approximate steel manufacture. The total energy use by this sector was $7,002 \mathrm{MJ}$, which represents $72 \%$ of the energy used for manufacture, and $71.5 \%$ of the overall energy use for the steel column case.

The sector's energy distribution by energy type is shown in Table 7, in which electricity and natural gas are prominent energy sources. 'Electricity' is made up of nuclear and hydro, which comprise $71 \%$ of the energy used to generate electricity in Canada. The remainder of the energy sources listed are fuels burned to either produce the remaining $29 \%$ of electricity, to power combustion engines or other processes.

\section{Conclusion}

The EIO-LCA model for Canada enables the quick and relatively straightforward estimation of cradle-togate GHG emissions and energy uses for materials, products or processes across their entire supply chain in the Canadian economy. As a consequence of considering the entire supply chain, both direct and indirect effects are computed, the former of which are only partially considered in conventional LCA. Moreover, the EIO-LCA technique is advantageous in that it uses data collected from Statistics Canada that is both reliable and centrally available. Finally, because the model uses the NAICS classification system, it lends itself to creating North American, multiregional models as environmental impacts cross national borders.

For all its advantages, the EIO-LCA model has limitations. First, the analyst is restricted to the data used by the model. This data is limited by the fact that in Canada, there are currently no national, producerspecific accounts of solid wastes, waterborne wastes, durable-good wastes, and recycling activities, and by the fact that there is no data on leakages from landfill sites, or on public sector wastes [17]. Secondly, though the model does have the advantage of considering the entire production supply chain, it is limited by the assumption that economic growth, environmental releases and energy inputs vary linearly with changes in demand. Thirdly, it is limited by aggregation. Some products and services are well approximated by their industry while others are not because they represent only a small portion of the sector's production and/or because they are vastly different from the average product or service in their sector. Analysts should also bear in mind that energy mixes may not reflect local conditions and that GHG emissions may not reflect emissions from certain processes. Fourth, the model considers only cradle-to-gate effects. When performing an LCA that includes substantial contributions from the use or end-of-life stages, a hybrid approach can be used where data are obtained from other sources or 
from other sectors of the EIO-LCA model [MacLean and Lave, 1998].

The EIO-LCA model points to several initiatives for moving toward a more sustainable economy. The first is to reduce economic activity in order to reduce environmental burdens. Since moving towards sustainability involves reducing GHG emissions and energy use (among many other concerns), the EIOLCA model supports the observation that less industrial activity improves society's environmental performance. The second initiative is related to industry (and consumers) making sounder environmental choices, such as the decision to use concrete rather than steel columns in office buildings. The final initiative is to change the structure of the economy through "greening" production processes and energy generation through technological innovation. In particular, since electricity generation is highly energy intensive, is widely used by other sectors in the economy and is often a large contributor to GHG emissions, the need for more research into clean power generation technologies is highlighted by EIO-LCA.

Without national environmental data and modeling capabilities, our capacity for a systems understanding of sustainability is limited. If innovative measurement technologies to aid material and energy flow accounting are developed from the bottom up within industry in response to increasingly strict environmental regulations, the informational basis for EIO-LCA will improve, and the technique will emerge as an important tool for moving toward sustainable design.

\section{References}

[1] U.S. Environmental Protection Agency and Science Applications International Corporation. LCAccess LCA 101, available at $<$ http://www.epa.gov/ORD/NRMRL/lcaccess/lca101.ht $\underline{\mathrm{m}}>, 2001$.

[2] International standards Organization (ISO), ISO 14040. Environmental Management - Life Cycle Assessment Principles and Framework, ISO, Geneva, Switzerland, 1998.

[3] Society of Environmental Toxicology and Chemistry (SETAC), Life-cycle impact assessment: the state-ofthe-art, Pensacola, Fla, 1997.

[4] Leontief, W., The Structure of the U.S. Economy, 19191939, MIT Press, Cambridge Massachussets, 1941.

[5] Hendrickson, C.T., A. Horvath, S. Joshi, and L.B. Lave, "Economic Input-Output Models for Environmental Life-Cycle Assessment", Environmental Science and Technology, American Chemical Society, April 1998, pp. 184A-191A.

[6] Horvath, A., and C.T. Hendrickson, "Steel vs. SteelReinforced Concrete Bridges: Environmental
Assessment", Journal of Infrastructure Systems, ASCE, September 1998, pp. 111-117.

[7] MacLean, H.L., and Lave, L.B., "A Life Cycle Model of an Automobile", Environmental Science and Technology, American Chemical Society, July 1998, pp. 322A-330A.

[8] Joshi, S., "Product Environmental Life-Cycle Assessment Using Input-Output Techniques", Journal of Industrial Ecology, MIT Press, March \& June 2000, pp. 95-120.

[9] Hendrickson, C.T., and A. Horvath, "Resource Use and Environmental Emissions of U.S. Construction Sectors. Journal of Construction Engineering and Management. ASCE. January/February 2000, pp. 38-44.

[10] Ruether, J. A., M. Ramezan, and P.C. Balash, "Greenhouse Gas Emissions from Coal Gasification Power Generation Systems", Journal of Infrastructure Systems, ASCE, September 2004, pp. 111-119.

[11] Carnegie Mellon Green Design Initiative, eio-lca.net: Economic Input-Output Life Cycle Assessment, available at $<$ http://eiolca.net $>, 2005$.

[12] Bjorn, A., L. Declerq-Lopez, S. Spatari, and H.L. MacLean, "Decision Support for Sustainable Development using a Canadian Economic Input-Output Life Cycle Assessment Model". Canadian Journal of Civil Engineering. National Research Council Research Press, Ottawa, Canada, 23 February 2005, pp. 16-29.

[13] Norman, J. "Development of a Canada-U.S. Environmental Input-Output Model: Working Paper Department of Civil Engineering", University of Toronto, Canada, July 2004.

[14] Miller, R.A., and P.D. Blair, Input-Output Analysis: Foundations and Extensions, Prentice Hall, Engelwood Cliffs, New Jersey, 1985.

[15] Statistics Canada, Standards Division, North American Industry Classification System, Canada, Ottawa, Canada, 1997.

[16] Statistics Canada, Systems of National Accounts Banch, Econnections: Linking the Environment and the Economy: Indicators and Detailed Statistics (STC 16200-XKE), available at $<$ http://www.statcan.ca:8096/bsolc/english/bsolc?catno= 16-200-X>, 2000.

[17] Statistics Canada, National Accounts and Environment Division, Econnections: Linking the Environment and the Economy: Concepts, Sources and Methods of the Canadian System of Environmental and Resource Accounts (Catalogue no. 16-505-GPE), Minister of Industry, Ottawa, Canada, 1997.

[18] Ferguson, J.H. (Senior Editor), RSMeans Square Foot Costs: $20^{\text {th }}$ Annual Edition. Kingston, MA, U.S., 1999.

[19] Organisation for Economic Co-Operation and Development (OECD), PPPs for GDP - Historical Series, available at $<$ http://www.oecd.org/std/ppp/>, 2005.

[20] Bank of Canada, Consumer Price Index, 1995- Present, available at $<$ http://www.bankofcanada.ca/en/cpi.htm $>$, 2005. 


\section{Appendix A}

Table A1. Canadian NAICS sectors

\begin{tabular}{|c|c|}
\hline $\begin{array}{l}\text { NAICS } \\
\text { Code }\end{array}$ & Industrial Sector Name \\
\hline $11 \mathrm{~A} 0$ & Crop and Animal Production \\
\hline 1130 & Forestry and Logging \\
\hline 1140 & Fishing, Hunting and Trapping \\
\hline 1150 & Support Activities for Agriculture and Forestry \\
\hline 2111 & Oil and Gas Extraction \\
\hline 2121 & Coal Mining \\
\hline 2122 & Metal Ore Mining \\
\hline 2123 & Non-Metallic Mineral Mining and Quarrying \\
\hline 2131 & $\begin{array}{l}\text { Support Activities for Mining and Oil and Gas } \\
\text { Extraction }\end{array}$ \\
\hline 2211 & $\begin{array}{l}\text { Electric Power Generation, Transmission and } \\
\text { Distribution }\end{array}$ \\
\hline $221 \mathrm{~A}$ & $\begin{array}{l}\text { Natural Gas Distribution, Water, Sewage and } \\
\text { Other Systems }\end{array}$ \\
\hline $230 \mathrm{~A}$ & Residential Building Construction \\
\hline $230 \mathrm{~B}$ & Non-residential Building Construction \\
\hline $230 \mathrm{C}$ & Transportation Engineering Construction \\
\hline 230D & Oil and Gas Engineering Construction \\
\hline $230 \mathrm{E}$ & Electric Power Engineering Construction \\
\hline $230 \mathrm{~F}$ & Communication Engineering Construction \\
\hline $230 \mathrm{G}$ & Other Engineering Construction \\
\hline $230 \mathrm{H}$ & Repair Construction \\
\hline $230 \mathrm{I}$ & Other Activities of the Construction Industry \\
\hline 3111 & Animal Food Manufacturing \\
\hline 3113 & $\begin{array}{l}\text { Sugar and Confectionery Product } \\
\text { Manufacturing }\end{array}$ \\
\hline 3114 & $\begin{array}{l}\text { Fruit and Vegetable Preserving and Specialty } \\
\text { Food Manufacturing }\end{array}$ \\
\hline 3115 & Dairy Product Manufacturing \\
\hline 3116 & Meat Product Manufacturing \\
\hline 3117 & Seafood Product Preparation and Packaging \\
\hline $311 \mathrm{~A}$ & Miscellaneous Food Manufacturing \\
\hline $312 \mathrm{~A}$ & Soft Drink and Ice Manufacturing \\
\hline 312B & Breweries \\
\hline $312 \mathrm{C}$ & Wineries \\
\hline $312 \mathrm{D}$ & Distilleries \\
\hline 3122 & Tobacco Manufacturing \\
\hline $31 \mathrm{~A} 0$ & Textile and Textile Product Mills \\
\hline 3160 & Clothing Manufacturing \\
\hline 3210 & Leather and Allied Product Manufacturing \\
\hline 3221 & Wood Product Manufacturing \\
\hline 3222 & Pulp, Paper and Paperboard Mills \\
\hline 3231 & Converted Paper Product Manufacturing \\
\hline 3241 & Printing and Related Support Activities \\
\hline 3251 & Petroleum and Coal Products Manufacturing \\
\hline 3252 & Basic Chemical Manufacturing \\
\hline 3253 & $\begin{array}{l}\text { Resin, Synthetic Rubber, and Artificial and } \\
\text { Synthetic Fibres and Filaments Manufacturing }\end{array}$ \\
\hline 3254 & $\begin{array}{l}\text { Pesticides, Fertilizer and Other Agricultural } \\
\text { Chemical Manufacturing }\end{array}$ \\
\hline $325 \mathrm{~A}$ & Pharmaceutical and Medicine Manufacturing \\
\hline
\end{tabular}

\begin{tabular}{|c|c|}
\hline 3261 & Miscellaneous Chemical Product Manufacturing \\
\hline 3262 & Plastic Product Manufacturing \\
\hline 3273 & Rubber Product Manufacturing \\
\hline $327 \mathrm{~A}$ & Cement and Concrete Product Manufacturing \\
\hline 3310 & $\begin{array}{l}\text { Miscellaneous Non-Metallic Mineral Product } \\
\text { Manufacturing }\end{array}$ \\
\hline 3320 & Primary Metal Manufacturing \\
\hline 3330 & Fabricated Metal Product Manufacturing \\
\hline 3341 & Machinery Manufacturing \\
\hline $334 \mathrm{~A}$ & $\begin{array}{l}\text { Computer and Peripheral Equipment } \\
\text { Manufacturing }\end{array}$ \\
\hline 3352 & Electronic Product Manufacturing \\
\hline $335 \mathrm{~A}$ & Household Appliance Manufacturing \\
\hline 3361 & $\begin{array}{l}\text { Electrical Equipment and Component } \\
\text { Manufacturing }\end{array}$ \\
\hline 3362 & Motor Vehicle Manufacturing \\
\hline 3363 & Motor Vehicle Body and Trailer Manufacturing \\
\hline 3364 & Motor Vehicle Parts Manufacturing \\
\hline 3365 & Aerospace Product and Parts Manufacturing \\
\hline 3366 & Railroad Rolling Stock Manufacturing \\
\hline 3369 & Ship and Boat Building \\
\hline 3370 & Other Transportation Equipment Manufacturing \\
\hline 3390 & Furniture and Related Product Manufacturing \\
\hline 4100 & Miscellaneous Manufacturing \\
\hline $4 \mathrm{~A} 00$ & Wholesale Trade \\
\hline 4810 & Retail Trade \\
\hline 4820 & Air Transportation \\
\hline 4830 & Rail Transportation \\
\hline 4840 & Water Transportation \\
\hline 4850 & Truck Transportation \\
\hline 4860 & Transit and Ground Passenger Transportation \\
\hline 48B0 & Pipeline Transportation \\
\hline 49A0 & $\begin{array}{l}\text { Scenic and Sightseeing Transportation and } \\
\text { Support Activities for Transportation }\end{array}$ \\
\hline 4930 & Postal Service and Couriers and Messengers \\
\hline $51 \mathrm{~A} 0$ & Warehousing and Storage \\
\hline 5120 & $\begin{array}{l}\text { Publishing Industries, Information Services and } \\
\text { Data Processing Services }\end{array}$ \\
\hline 5131 & Motion Picture and Sound Recording Industries \\
\hline $513 \mathrm{~A}$ & Radio and Television Broadcasting \\
\hline $5 \mathrm{~A} 01$ & $\begin{array}{l}\text { Pay TV, Specialty TV and Program Distribution } \\
\text { and Telecommunications }\end{array}$ \\
\hline $5 \mathrm{~A} 02$ & $\begin{array}{l}\text { Monetary Authorities and Depository Credit } \\
\text { Intermediation }\end{array}$ \\
\hline $5 \mathrm{~A} 03$ & Insurance Carriers \\
\hline $5 \mathrm{~A} 04$ & Lessors of Real Estate \\
\hline $5 \mathrm{~A} 05$ & Owner-Occupied Dwellings \\
\hline $5 \mathrm{~A} 06$ & $\begin{array}{l}\text { Rental and Leasing Services and Lessors of } \\
\text { Non-Financial Intangible Assets (except } \\
\text { Copyrighted Works) }\end{array}$ \\
\hline $541 \mathrm{~A}$ & $\begin{array}{l}\text { Other Finance, Insurance and Real Estate and } \\
\text { Management of Companies and Enterprises }\end{array}$ \\
\hline 5418 & $\begin{array}{l}\text { Legal, Accounting and Architectural, } \\
\text { Engineering and Related Services }\end{array}$ \\
\hline 541B & Advertising and Related Services \\
\hline 5610 & $\begin{array}{l}\text { Computer Systems Design and Other } \\
\text { Professional, Scientific and Technical Services }\end{array}$ \\
\hline 5620 & Administrative and Support Services \\
\hline
\end{tabular}




\begin{tabular}{ll}
\hline 611 A & Waste Management and Remediation Services \\
\hline 62 A0 & Educational Services (except Universities) \\
\hline 7100 & $\begin{array}{l}\text { Health Care Services (except Hospitals) and } \\
\text { Social Assistance }\end{array}$ \\
\hline 7200 & Arts, Entertainment and Recreation \\
\hline 8110 & Accommodation and Food Services \\
\hline 81 A0 & Repair and Maintenance \\
\hline 813 A & $\begin{array}{l}\text { Personal and Laundry Services and Private } \\
\text { Households }\end{array}$ \\
\hline F101 & $\begin{array}{l}\text { Grant-Making, Civic, and Professional and } \\
\text { Similar Organizations }\end{array}$ \\
\hline F103 & Operating Supplies \\
\hline F104 & Caffice Supplies \\
\hline F201 & Laboratory Supplies \\
\hline F202 & Travel and Entertainment \\
\hline F300 & Advertising and Promotion \\
\hline NP11 & Transportation Margins \\
\hline NP12 & Religious Organizations \\
\hline NP13 & Non-Profit Welfare Organizations \\
\hline NP20 & Non-Profit Sports and Recreation Clubs \\
\hline NP19 & Non-Profit Education Institutions \\
\hline GS11 & $\begin{array}{l}\text { Other Non-Profit Institutions Serving } \\
\text { Households }\end{array}$ \\
\hline GS12 & Hospitals \\
\hline GS21 & Government Residential Care Facilities \\
\hline GS22 & Universities \\
\hline GS60 & Government Education Services \\
\hline GS50 & $\begin{array}{l}\text { Other Municipal Government Services } \\
\text { Services }\end{array}$ \\
\hline GS60 & Other Federal Government Services \\
\hline & \\
\hline GSial and Territorial Government \\
\hline For
\end{tabular}

